\title{
Universiteit
}

Leiden

The Netherlands

\section{A novel function of Streptomyces integration host factor (sIHF) in the control of antibiotic production and sporulation in Streptomyces} coelicolor

Yang, Y.H.; Song, E.; Willemse, J.; Park, S.H.; Kim, W.S.; Kim, E.J.; ... ; Kim, B.G.

\section{Citation}

Yang, Y. H., Song, E., Willemse, J., Park, S. H., Kim, W. S., Kim, E. J., ... Kim, B. G. (2012). A novel function of Streptomyces integration host factor (sIHF) in the control of antibiotic production and sporulation in Streptomyces coelicolor. Antonie Van Leeuwenhoek, 101(3), 479-492. doi:10.1007/s10482-011-9657-z

Version:

License:

Downloaded from:
Publisher's Version

Licensed under Article 25fa Copyright Act/Law (Amendment Taverne)

https://hdl.handle.net/1887/22960

Note: To cite this publication please use the final published version (if applicable). 


\title{
A novel function of Streptomyces integration host factor (sIHF) in the control of antibiotic production and sporulation in Streptomyces coelicolor
}

\author{
Yung-Hun Yang $\cdot$ Eunjung Song $\cdot$ Joost Willemse $\cdot$ Sung-Hee Park $\cdot$ \\ Woo-Seong Kim • Eun-jung Kim • Bo-Rahm Lee $\cdot$ Ji-Nu Kim • \\ Gilles P. van Wezel • Byung-Gee Kim
}

Received: 15 August 2011/ Accepted: 11 October 2011/Published online: 29 October 2011

(C) Springer Science+Business Media B.V. 2011

\begin{abstract}
Bacterial integration host factors (IHFs) play important roles in site-specific recombination, DNA replication, transcription, genome organization and bacterial pathogenesis. In Streptomyces coelicolor, there are three putative IHFs: SCO1480, SCO2950 and SCO5556. SCO1480 or Streptomyces IHF (sIHF) was previously identified as a transcription factor that binds to the promoter region of redD, the pathway-specific regulatory gene for the undecylprodigiosin biosynthetic gene cluster. Here we show that production of the pigmented antibiotics actinorhodin
\end{abstract}

Yung-Hun Yang and Eunjung Song have contributed equally to this work.

Electronic supplementary material The online version of this article (doi:10.1007/s10482-011-9657-z) contains supplementary material, which is available to authorized users.

\section{Y.-H. Yang}

Department of Microbial Engineering, College

of Engineering, Konkuk University, Seoul, Korea

E. Song · S.-H. Park · W.-S. Kim · E. Kim ·

B.-R. Lee · J.-N. Kim · B.-G. Kim $(\square)$

School of Chemical and Biological Engineering

and Institute of Bioengineering, Seoul National

University, Seoul, Korea

e-mail: byungkim@snu.ac.kr

J. Willemse · G. P. van Wezel

Molecular Biotechnology, Leiden Institute of Chemistry, Leiden University, PO Box 9502, 2300 RA Leiden,

The Netherlands and undecylprodigiosin is strongly enhanced in sihf null mutants, while sporulation was strongly inhibited, with an on average 25\% increase in spore size. Furthermore, the sihf mutant spores showed strongly reduced viability, with high sensitivity to heat and live/dead staining revealing a high proportion of empty spores, while enhanced expression of sIHF increased viability. This suggests a major role for sIHF in controlling viability, perhaps via the control of DNA replication and/or segregation. Proteomic analysis of the sihf null mutant identified several differentially expressed transcriptional regulators, indicating that sIHF may have an extensive response regulon. These data surprisingly reveal that a basic architectural element conserved in many actinobacteria such as mycobacteria, corynebacteria, streptomycetes and rhodococci may act as a global regulator of secondary metabolism and cell development.

Keywords DNA replication - Chromosome segregation · Development · Nucleoid · HU · IHF

\section{Introduction}

Bacterial integration host factors (IHFs) play important roles in site-specific recombination, DNA replication, transcription, genome organization and bacterial pathogenesis (Pedulla et al. 1996; Mangan et al. 2006). IHF binds a conserved DNA sequence, and changes the conformation by locally bending the 
DNA (Rice 1997). IHF is known to promote longrange interactions in several systems (Goosen and van de Putte 1995) and affects local DNA conformational structures critical to transcription control.

A new type of IHF was first identified and studied in mycobacteria, which is essential for their survival, but shares relatively low amino acid identity to the canonical IHF (Pedulla and Hatfull 1998; Pedulla et al. 1996). Mycobacterial IHF (mIHF) has several orthologs in actinobacteria, including corynebacteria, streptomycetes and rhodococci, and we propose to refer to the family as actinobacterial IHF (aIHF). mIHF itself is an unusual host factor and is required for the formation of recombinogenic intasomes, which are nucleoprotein complexes active in the integration of bacteriophage DNA into host DNA (Pedulla and Hatfull 1998). However, mIHF does not specifically bind to the site of integration (L5 attP). The different types of IHFs act as architectural elements that control transcription by facilitating the formation of DNAprotein complexes, and/or function as direct transcriptional regulators by themselves without involvement of any other transcription factors (Goosen and van de Putte 1995).

In Streptomyces coelicolor, a model antibiotic producer (Bentley et al. 2002; Bibb 2005; van Wezel and McDowall 2011), there are three putative IHFs: SCO1480, SCO2950 and SCO5556 (http://strepdb. streptomyces.org.uk/ (Streptomyces database website)). Recently, SCO2950 was revealed as the conventional nucleoid-associated HU protein, HupA that is similar to Escherichia coli $\mathrm{HU} \alpha$ and $\mathrm{HU} \beta$ (Salerno et al. 2009). It also shows high homology with known IHFs such as $\operatorname{HimA}(\operatorname{Ihf} \alpha)$ and $\operatorname{HimD}(\operatorname{Ihf} \beta)$ from $E$. coli (Supplementary Fig. 1). Another HU-family protein, SCO5556, contains N-terminal part similar to $\mathrm{HU}$ proteins and a C-terminal domain similar to the alanine- and lysine-rich $\mathrm{C}$ termini of eukaryotic linker histones. Such two-domain HU proteins were found to exist only in actinobacteria, and designated as HupS (Salerno et al. 2009).

It is known that the IHF is structurally and functionally similar to histone-like protein $\mathrm{HU}$ in E. coli (Takeuchi et al. 2002). HU often compensates for the absence of IHF in some cellular functions such as cell growth and replication of oriC plasmids (Kano et al. 1991), but IHF cannot compensate for the absence of HU in the cell, even though the IHF and HU share over $30 \%$ of amino acid identity (Boubrik et al.
1991). IHFs in E. coli have pleiotropic functions, and besides being involved in crucial cellular functions, they have also been reported to directly control the transcription of at least 59 operons (Karp et al. 2002).

We previously reported that SCO1480, which is a member of the aIHF family with high sequence homology to $\mathrm{mIHF}$, binds to the promoter regions of actII-ORF4 and redD, which encode the pathwayspecific activators for actinorhodin (ACT) and undecylprodigiosin (RED) biosynthesis, respectively (Park et al. 2009). Unlike other well-known IHF homologs, the sequence of SCO1480 (Streptomyces IHF, SIHF) is conserved only in actinobacteria such as mycobacteria, corynebacteria, streptomycetes, and rhodococci, but its function has been only reported in mycobacteria (Pedulla and Hatfull 1998). To obtain more detailed insight into the transcriptional regulatory role of Streptomyces IHF (further referred to as SIHF), we scrutinized the sihf (SCO1480) null mutant in terms of growth, antibiotic production and development. This is the first study of a different role of an aIHF, known as one of basic architectural units (Charlier et al. 1995; Devroede et al. 2006), on secondary metabolisms in Streptomyces.

\section{Materials and methods}

Bacterial strains and media composition

All of the E. coli and Streptomyces strains used in this experiment are listed in Table 1. Cultivation of $S$. coelicolor strains followed the standard procedures (Kieser et al. 2000). Briefly, fresh M145 spores were collected on $\mathrm{R}^{-}$media composed of $103 \mathrm{~g}$ sucrose, $0.25 \mathrm{~g} \mathrm{~K}_{2} \mathrm{SO}_{4}, 10.12 \mathrm{~g} \mathrm{MgCl} \cdot 6 \mathrm{H}_{2} \mathrm{O}, 10 \mathrm{~g}$ glucose, $0.1 \mathrm{~g}$ Difco casamino acids, $5 \mathrm{~g}$ yeast extract, $5.73 \mathrm{~g}$ TES buffer, $7 \mathrm{ml}$ of $1 \mathrm{~N} \mathrm{NaOH}$, and $2 \mathrm{ml}$ of a trace element solution in 11 of distilled water. Minimal media with different amino acids and sugars contained $0.5 \mathrm{~g}$ amino acid, $0.5 \mathrm{~g} \mathrm{~K}_{2} \mathrm{HPO}_{4}, 0.2 \mathrm{~g} \mathrm{MgSO}_{4} \cdot 7 \mathrm{H}_{2} \mathrm{O}$, and $10 \mathrm{~g}$ sugar as carbon source with $0.01 \mathrm{~g} \mathrm{FeSO}_{4} \cdot 7 \mathrm{H}_{2} \mathrm{O}$ in 11 of distilled water. Mannitol soya flour medium (SFM) is composed of $20 \mathrm{~g}$ agar, $20 \mathrm{~g}$ of mannitol, $8 \mathrm{~g}$ of soya flour, made up to 11 with tap water.

Protein over-expression in E. coli

For the expression of SCO1480 with a C-terminal $6 \times$ His-tag, the coding region was amplified by PCR 
Table 1 Bacterial strains, plasmids, and primers used in this study

\begin{tabular}{|c|c|c|}
\hline $\begin{array}{l}\text { Strains, plasmids, } \\
\text { and primers }\end{array}$ & Relevant information & $\begin{array}{l}\text { Source or } \\
\text { reference }\end{array}$ \\
\hline \multicolumn{3}{|l|}{ Bacterial strains } \\
\hline \multicolumn{3}{|l|}{ E. coli strains } \\
\hline $\mathrm{DH} 5 \alpha$ & $\begin{array}{c}\mathrm{F}^{-} \varphi 80 \text { lacZ M15 endA recA hsdR }\left(\mathrm{r}_{\mathrm{k}}{ }^{-} \mathrm{m}_{\mathrm{k}}{ }^{-}\right) \\
\text {supE thi gyrA relA } \Delta(\text { lacZYA-argF }) \mathrm{U} 169\end{array}$ & Laboratory stock \\
\hline BL21(DE3) & $\mathrm{F}^{-} \operatorname{omp} T h s d S_{B}\left(\mathrm{r}_{\mathrm{B}}{ }^{-} \mathrm{m}_{\mathrm{B}}^{-}\right)$gal dcm & Novagen \\
\hline JM110 & $\mathrm{dam}^{-}, \mathrm{dcm}^{-}$ & Laboratory stock \\
\hline BW25113 & K12 derivative: $\triangle a r a B A D, \triangle r h a B A D$ & Gust et al. (2003) \\
\hline \multicolumn{3}{|l|}{ S. coelicolor } \\
\hline A3(2) M145 & $\mathrm{SCP}^{-}{ }^{-}, \mathrm{SCP}_{2}^{-}, \mathrm{Pgl}^{+}$ & KCTC \\
\hline BG716 & SCO1480 deleted mutant & This study \\
\hline BG7161 & BG716 carrying pYH81 & This study \\
\hline BG7164 & M145 carrying pYH81 & This study \\
\hline BG7165 & BG716 carrying pEJ70 & This study \\
\hline \multicolumn{3}{|l|}{ Plasmids } \\
\hline pET24ma & $\begin{array}{l}\text { p15A replication origin, } \mathrm{T} 7 \text { lac promoter, } \mathrm{C} \text {-terminal } \\
\text { his-tag coding, } \text { kan }^{\mathrm{R}}\end{array}$ & Yang et al. (2005) \\
\hline pIBR25 & $\begin{array}{l}\text { pWHM3 carrying ermE* promoter }(E c o \mathrm{RI} / K p n \mathrm{I}) \text { from } \\
\text { Saccharopolyspora erythraea }\end{array}$ & Thuy et al. (2005) \\
\hline pSET152-neo & $\begin{array}{l}\text { Apramycin resistance gene-deleted pSET152 (Streptomyces integration } \\
\text { vector) harboring neomycin resistance gene }\end{array}$ & This study \\
\hline pYH80 & pET24ma carrying PCR product of SCO1480 from S. coelicolor & This study \\
\hline pYH81 & pIBR25 carrying PCR product of SCO1480 from S. coelicolor & This study \\
\hline pEJ70 & $\begin{array}{l}\text { pSET152-neo carrying PCR product of SCO1480 together with } \\
223 \text { bp upstream of SCO1480 as promoter }\end{array}$ & This study \\
\hline pIJ773 & $\operatorname{aac}(3) I V\left(\operatorname{apra}^{R}\right)+$ oriT & Gust et al. (2003) \\
\hline \multicolumn{3}{|l|}{ Primers } \\
\hline 1480-E. coli & $\begin{array}{l}\text { CGTGGATCCGTGGCTCTTCCGCCCCTTAC/ACGAAGCTTTCAGTGGT } \\
\text { GGTGGTGGTGGTGGCTGCCGGTGCTGCCGA }\end{array}$ & \\
\hline $1480-\mathrm{St}$ & $\begin{array}{l}\text { CGTCGTGGATCCGTCGTCGGGCGAGCGTGTTGC/CGTCGTAAGCTT } \\
\text { TCAGCTGCCGGTGCTGCCGAA }\end{array}$ & \\
\hline $1480+$ prom-St & $\begin{array}{l}\text { ATAATAT GCGGCCG CCCTGGATACATCCTCAAATC/ATAAT TCTAGA } \\
\text { GACTCAGCTGCCGGTGCTGC }\end{array}$ & \\
\hline Del-1480F & $\begin{array}{l}\text { CGTATCCGACAGTTCGACATCCGAGGTGACGTAGGC GTGATTCCGGG } \\
\text { GATCCGTCGACC }\end{array}$ & \\
\hline Del-1480B & $\begin{array}{l}\text { CAGCGATTATTCCAGCAATCCCGGAGTGGTCCGGAC TCATGTAGGCTG } \\
\text { GAGCTGCTTC }\end{array}$ & \\
\hline Del-confirm & CTGACCAGGACTTTTCCGCTG/GAGACCGACAGCCATACCTCG & \\
\hline Neomycin & $\begin{array}{l}\text { ATATAT GAGCTC ATGATTGAA CAAGATGGAT/ATATAT GAGCTC TCA } \\
\text { GAAGAACTCGTCAAGAAG }\end{array}$ & \\
\hline EMSA-redZ & CCGGCGCGCGGACGCCGCCGTGCA/ACGTTGACTTTCGTCCAGGAAGGA & \\
\hline EMSA-sihf & GTCCCGACGTGACCGCGTTGCGGA/GCCTACGTCACCTCGGATGTCGAA & \\
\hline EMSA-pyrRbldD & CATATGGCTCCCCGGACAAGGTGT/ACGAAACGGACCCССТTCTCCGCC & \\
\hline
\end{tabular}


using S. coelicolor chromosomal DNA as a template and the primers listed in Table 1. The amplified fragments were digested with BamHI plus HindIII and cloned into pET24ma. After no errors in PCR were confirmed by nucleotide sequencing, the constructed plasmids were transformed into E. coli BL21. Cells harboring each plasmid were grown at $37^{\circ} \mathrm{C}$ in $50 \mathrm{ml} \mathrm{LB}$ broth with $50 \mu \mathrm{g} / \mathrm{ml}$ kanamycin. When the culture reached an absorbance of approximately A600 of 0.6, protein expression was induced with $0.1 \mathrm{mM}$ isopropyl thio- $\beta$-D-galactopyranoside. After $6 \mathrm{~h}$ at $30^{\circ} \mathrm{C}$, cells were washed twice with $20 \mathrm{ml}$ ice-cold phosphate buffered saline (PBS) and resuspended with $5 \mathrm{ml}$ Buffer I $(50 \mathrm{mM}$ phosphate buffer $\mathrm{pH} 8.0,0.01 \%$ Tween 20 , and $100 \mathrm{mM} \mathrm{NaCl}$ supplemented with $20 \mathrm{mM}$ imidazole) and then sonicated for $20 \mathrm{~min}$ in an ice bath. Cell debris was removed by centrifugation. The resultant supernatant was applied to Ni-NTA (Qiagen) mini-column preequilibrated with buffer I. His-tagged proteins were eluted with $1 \mathrm{ml}$ of elution buffer $(50 \mathrm{mM}$ phosphate buffer $\mathrm{pH} 8.0,0.01 \%$ Tween 20 , and $100 \mathrm{mM} \mathrm{NaCl}$ supplemented with $250 \mathrm{mM}$ imidazole). The purified protein concentration was measured using a Bradford assay (Bio-Rad, USA) and the samples were stored at $-20^{\circ} \mathrm{C}$ until further use.

Electrophoretic mobility shift assay (EMSA)

PCR amplified DNA fragments containing the promoters of redZ, sihf and pyrR-bldD were prepared using the relevant primers (Table 1) and radiolabeled with $\mathrm{T} 4$ polynucleotide kinase in the presence of $\left[\gamma-{ }^{32} \mathrm{P}\right]$-dATP, and the unreacted $\left[\gamma-{ }^{32} \mathrm{P}\right]-\mathrm{dATP}$ was removed using ProbeQuant ${ }^{\text {TM }}$ G-50 Micro Columns (GE Healthcare, USA). The labeled probes were incubated with His-tag purified sIHF at $37^{\circ} \mathrm{C}$ for $10 \mathrm{~min}$ followed by an ice bath for $30 \mathrm{~min}$. The total volume containing $20 \mathrm{mM}$ HEPES ( $\mathrm{pH} 7.8), 10 \% \mathrm{w} / \mathrm{v}$ glycerol, $100 \mathrm{mM} \mathrm{KCl}, 0.05 \mathrm{mM}$ EDTA, $5 \mathrm{mM}$ $\mathrm{MgCl}_{2}, 0.5 \mathrm{mM}$ dithiothreitol, $0.01 \%$ Nonidet P-40, and $2 \mu \mathrm{g}$ sheared salmon sperm DNA (sssDNA) was $20 \mu 1$. Protein-bound DNA and free DNA were resolved on $5 \%$ acrylamide gel in $0.5 \times$ TBE buffer at room temperature. The gel was exposed overnight. Audoradiography was performed overnight and analyzed with a Typhoon 8600 scanner (GE Healthcare, USA).
Construction of deletion mutants

Using the PCR-targeted Redirect method (Gust et al. 2003), the complete coding region of SCO1480 (sihf) located on S. coelicolor cosmid clone St9C5 (obtained from the John Innes Centre, Norwich, UK) was replaced by the apramycin resistance gene $\operatorname{aac}(3) I V$. For this construction, oligonucleotide primers (Table 1) were designed such that one contained the $-36 /+3$ region relative to the start of SCO1480 as well as the upstream pIJ773 priming site, and the second the stop codon and 36 nt downstream region of SCO1480 as well as the downstream pIJ773 priming site; following PCR amplification using pIJ773 as the template, the DNA fragment was used to generate a knock-out cosmid based on the Redirect technology (Gust et al. 2003), which was then used for the replacement of SCO1480 by the apramycin resistance cassette aac 44 (Table 1). For this, the mutated cosmid was introduced by conjugation into $S$. coelicolor M145 and colonies were selected that had undergone homologous recombination, with the desired double recombinants carrying apramycin resistance, while being sensitive to kanamycin, the selectable marker for the vector sequences. The deletion of SCO1480 was confirmed by sequencing the corresponding PCR products and by complementation (Table 1). The mutant was designated BG716. In this study, BG7161 and BG7165 were constructed for the complementation of SCO1480 (Table 1). In BG7161, SCO1480 is cloned in a multicopy vector based on pIBR25, harbouring the sihf gene behind the ermE* $^{*}$ promoter. In BG7165, SCO1480 is cloned in the promoter-less pSET152-neo integration vector. To express sihf from its native promoter, the sihf gene with 223 bp upstream region was cloned as a NotIXbaI fragment into pSET152-neo, a derivative of pSET152 (Bierman et al. 1992) harbouring the neomycin resistance cassette $a p h$, thus generating BG7165.

ACT and undecylprodigiosin antibiotics measurement

Mycelia of M145 and BG716 were cultured on R5 ${ }^{-}$agar plates and circular agar blocks (5 $\mathrm{mm}$ diameter) containing the cells were taken each day. The samples were stored at $-20^{\circ} \mathrm{C}$ until use. The agar blocks were mashed and sonicated after treating with $1 \mathrm{~N} \mathrm{KOH}$. After the 5 min of incubation, samples were centrifuged and the $\mathrm{A}_{630}$ of the supernatants was measured spectrophotometrically. The remaining cells were washed 
twice with double distilled water (DDW), and the amount of RED was determined as a measure of the $\mathrm{A}_{530}$ following extraction with $\mathrm{HCl}$-acidified methanol $(\mathrm{pH}$ 2). Absorbance was measured using a 96-well plate in a multiscanner (Thermo Scientific, USA). The experiments were all performed in triplicate.

\section{Scanning electron microscopy}

The spores and hyphae of M145 and BG716 strains were observed by scanning electron microscopy (SEM) (JEOL JSM 5410LV) after 7 days of growth on minimal media containing leucine and glycerol without iron ion $\left(\mathrm{FeSO}_{4} \cdot 7 \mathrm{H}_{2} \mathrm{O}\right)$. The cut agar blocks were pre-fixed by $2 \%$ paraformaldehyde and $2 \%$ glutaraldehyde in $0.05 \mathrm{M}$ sodium cacodylate buffer (pH 7.2) and post-fixed by $1 \%$ osmium tetroxide in $0.05 \mathrm{M}$ sodium cacodylate buffer $(\mathrm{pH}$ 7.2) for $2 \mathrm{~h}$, then dehydrated and dried. Each sample was sputtercoated and examined by SEM.

Fluorescence microscopy and live/dead staining

Cell membranes were stained using a $0.2 \mu \mathrm{g} / \mathrm{ml}$ solution of $\mathrm{FM}^{\circledR}$ 5-95 (N-(3-trimethylammoniumpropyl)-4-(6-(4-(diethylamino) phenyl) hexatrienyl) pyridinium-dibromide; absorbance $560 \mathrm{~nm} / \mathrm{emission}$ $734 \mathrm{~nm}$ ) prepared in Hanks' balanced salt solution. To analyse viability, the ratio of live/dead cells was determined by staining nucleic acids with a combination of the green-fluorescent SYTO ${ }^{\circledR} 82$ stain (540/ $560 \mathrm{~nm}$ ) and the red-fluorescent PI (propidium iodide; 535/617 nm) (Willemse and van Wezel 2009). All dyes were obtained from Molecular Probes, Inc (Eugene). Imaging was done as described previously (Willemse et al. 2011), using a Zeiss Axioscope A1 upright fluorescence microscope making use of a Axiocam Mrc5 camera at a resolution of $37.5 \mathrm{~nm} /$ pixel. The green fluorescent images were created using $470 / 40 \mathrm{~nm}$ band pass excitation and 525/50 band pass detection, for the red channel $550 / 25 \mathrm{~nm}$ band pass excitation and 605/70 band pass detection were used.

Cell viability test

All strains were cultured in $100 \mathrm{ml}$ flasks for $20 \mathrm{~h}$ in complex R5 ${ }^{-}$liquid media, harvested and washed twice with DDW. The same amount of colony forming units (cfu) was taken for each strain and incubated in $60^{\circ} \mathrm{C}$ water bath for 0,10 or $20 \mathrm{~min}$. For each time point a $10 \mu \mathrm{l}$ suspension was taken and serially diluted. Samples were then plated onto $\mathrm{R}^{-}$agar plates to count the cfu.

Two-dimensional gel analysis

WT and BG716 spread onto cellophane-covered solid minimal media containing glucose and glycine (MMGG) as a C-source and $\mathrm{N}$-source, respectively, were cultured for 5 days. Then cells were harvested with spatula, resuspended and washed twice with PBS $(\mathrm{pH}$ 7.4) containing $137 \mathrm{mM} \mathrm{NaCl}, 2.7 \mathrm{mM} \mathrm{KCl}, 10 \mathrm{mM}$ $\mathrm{Na}_{2} \mathrm{HPO}_{4}$, and $2 \mathrm{mM} \mathrm{KH} \mathrm{PO}_{4}$. After the cell pellets were disrupted by sonication, the concentration of cytosolic protein was determined by a Bradford assay. Protein extracts $(300 \mu \mathrm{g})$ were mixed with $350 \mu \mathrm{l}$ of rehydration solution and were separated by isoelectric focusing followed by polyacrylamide gel electrophoresis as described previously (Yang et al. 2010). Then gel images were analyzed by ImageMaster ${ }^{\mathrm{TM}}$ 2D Platinum Software (GE Healthcare). Differentially expressed spots were tryptic digested and subjected to nLC-MS/ MS (Ultimate 3000, Dionex) (LTQ orbitrap, Thermo Scientific) for peptide analysis. Proteins were identified unambiguously because two or more peptides that are detected more than three times having cross-correlation scores (Xcorr) of equal or greater than 1.7 for singlycharged, 2.5 for doubly-charged, and 3.0 for triplycharged peptides are only selected.

Sequence alignment

Protein sequences of CarA, CarB, PyrD, PyrF, HU, IHF, and aIHF orthologs of mycobacteria and streptomycetes were obtained from NCBI (http://www.ncbi.nlm.nih. gov/sites/entrez/ (Benson et al. 1998)). ClustalX 1.81 (Thompson et al. 1997) and GeneDoc2.6.002 (Nicholas et al. 2002) were used to generate and edit the multiple alignments, respectively. MEGA5.05 (Tamura et al. 2011) was used to draw the phylogenetic tree.

\section{Results}

Genomic environment for aIHF genes

in mycobacteria and streptomycetes

The putative sIHF (SCO1480) shares relatively low homology (43\% aa identity) to mIHF, the 


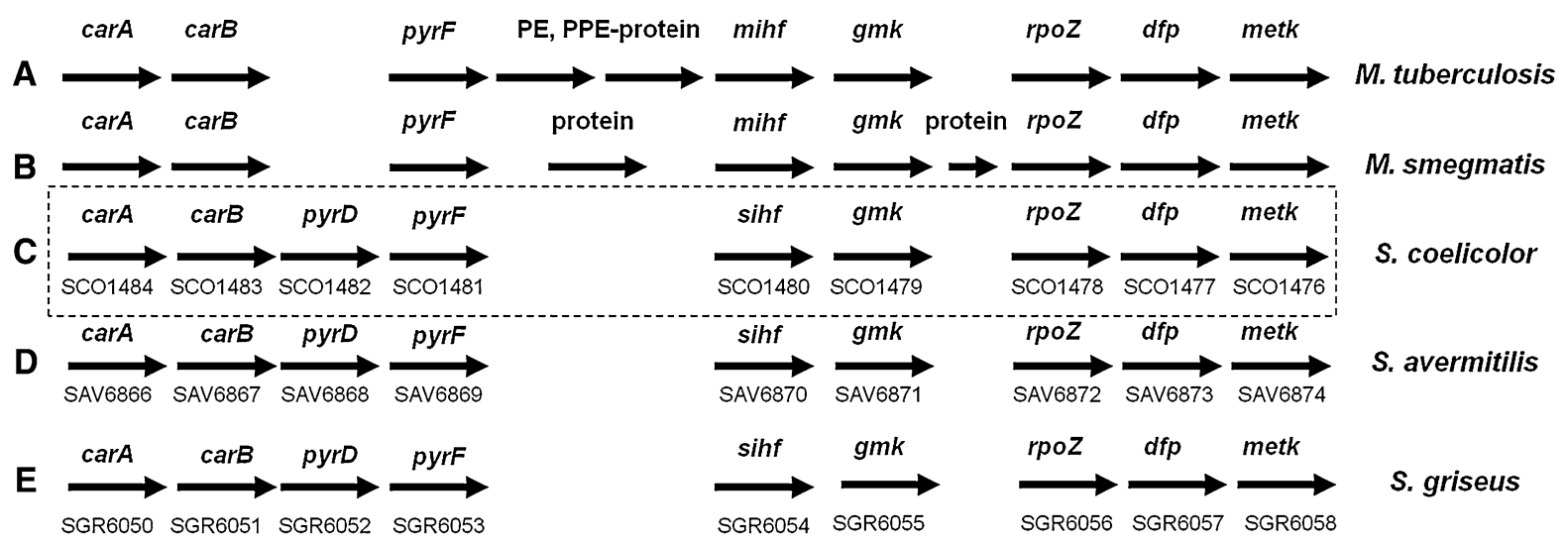

Fig. 1 Genetic environment for the actinobacterial ihf gene (aihf) in mycobacteria (a-b) and streptomycetes $(\mathbf{c}-\mathbf{e})$ species. The gene products for the genes are as follows; carA: (pyrAA), carbamoyl phosphate synthase small chain, carB: (pyrA) carbamoyl phosphate synthase large chain, $p y r D$ : dihydroorotate

IHF from Mycobacterium smegmatis. However, gene synteny evidence strongly suggests that SCO1480 indeed encodes SIHF, as the genetic environment of the ihf genes of $M$. smegmatis and $S$. coelicolor is highly similar, and both genes are located within a cluster of genes related to nucleotide biosynthesis and metabolism; these include the upstreamlocated $c a r A B$ for carbamoylphosphate synthase and pyrF for pyrimidine synthetase, and the downstreamlocated gmk (for guanylate kinase), rpoZ (for the omega subunit of the RNA polymerase) and metK (for S-adenosylmethionine synthetase). A similar organization is found for the genes for aIHF orthologues in other actinobacteria (Fig. 1).

sIHF has a DNA binding activity that corresponds to architectural proteins

DNA affinity capture assays and EMSAs identified sIHF as a transcription factor that could bind to the promoter regions of actII-ORF4 and redD, the pathway-specific activator genes for ACT and RED production, respectively (Park et al. 2009). To further analyse the role of SIHF in the control of antibiotic production, we also examined whether sIHF could bind to the promoter of redZ, encoding a response regulator that activates the transcription of redD (Guthrie et al. 1998). For this, C-terminally His $6^{-}$ tagged SIHF was purified following routine procedures and incubated with a ${ }^{32} \mathrm{P}$-radiolabelled DNA probe dehydrogenase, pyrF: orotidine $5^{\prime}$-phosphate decarboxylase, gmk: guanylate kinase, rpoZ: omega subunit of RNA polymerase, $d f p$ : DNA/pantothenate metabolism flavoprotein, metK: $\mathrm{S}$-adenosylmethionine synthetase

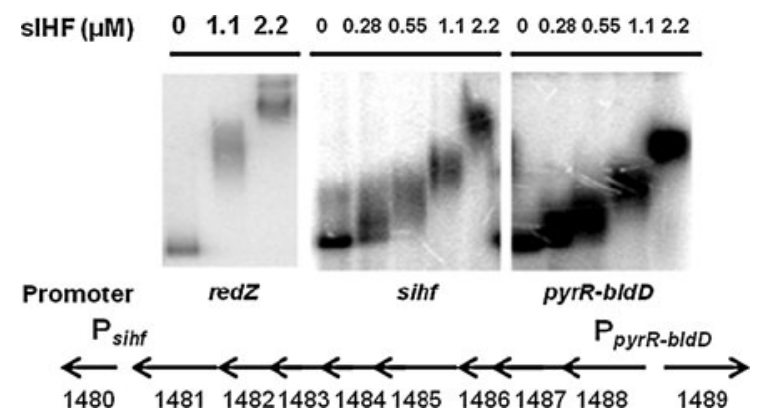

Fig. 2 DNA binding studies of purified sIHF-His ${ }_{6}$ with the redZ, $\operatorname{sih} F$ and pyrR-bldD promoter regions, with different amounts of purified sIHF in each lane as indicated. The relative location of the sihf and pyrR-bldD genes is indicated. For gene organization and SCO numbers see also Fig. 1

encompassing the $300 \mathrm{bp}$ region upstream of the start codon of redZ. This indeed revealed good binding of sIHF-His $_{6}$ to the redZ promoter region (Fig. 2). Finally, sIHF also binds its own promoter and a probe corresponding to the pyrR-bldD intergenic region, with PyrR controlling pyrimidine biosynthesis and BldD a key regulator of development in S. coelicolor (Lee et al. 2007) (Fig. 2). In all cases, the probes showed stronger retardation at higher concentrations of sIHF, suggesting that multiple sIHF molecules bound to the DNA simultaneously, in line with the mode of binding for architectural proteins in mycobacteria (Pedulla and Hatfull 1998; Pedulla et al. 1996). Additionally, IHF-like proteins are known to 
have low sequence specificity, which is also true for the orthologous mIHF in mycobacteria (Pedulla et al. 1996). Indeed, sIHF-His 6 was also shown to bind the upstream regions of genes such as $s c b R$ and $\operatorname{rok} 7 B 7$ (SCO6008) and was inhibited by higher concentrations of salmon sperm DNA. Thus, SIHF has a similar mode of DNA binding as other IHF orthologues, including $\mathrm{mIHF}$.

Deletion of the gene for sIHF enhances antibiotic production

To investigate the role of sIHF in the control of growth and development, a SCO1480 null mutant was created (BG716) using PCR-targeted gene replacement. While $m I H F$ is essential in M. tuberculosis (Cole et al. 1998), null mutants for sihf could be readily obtained in S. coelicolor. When grown under various conditions and on different carbon sources, BG716 showed major changes in production of pigmented antibiotics in comparison to the parental strain M145, with enhanced antibiotic production in minimal media as well as in R5 ${ }^{-}$complex media (Fig. 3a). To confirm that the enhanced antibiotic production was solely due to the deletion of sihf, a complementation experiment was performed by introducing plasmid pEJ70 harbouring a wild-type copy of SCO1480 into the sihf null mutant BG716 (for the promoter, $223 \mathrm{bp}$ upstream of SCO1480 was cloned together with SCO1480). Another complementation strain was made by using plasmid pYH81 which expresses sihf from the constitutive $e r m E^{*}$ promoter. Antibiotic production on glucose/glycine minimal media was then examined. While M145 produced little pigmented antibiotics (ACT or RED) under these conditions, the sihf null mutant BG716 produced significant amounts of ACT and RED; however, antibiotic production was reduced again following complementation by constructs expressing sihf in both ways (BG7161 and BG7165). These complementation experiments strongly suggest that the enhanced production of ACT was solely due to the deletion of sinf (Fig. 3b). Antibiotic production was quantitatively measured and BG716 produced approximately 1.4-fold more ACT and 1.9-fold more RED as compared to the parent M145 (Fig. 3c, d).

sIHF is required for proper sporulation and for spore integrity

To analyse role of sIHF in the control of development, S. coelicolor M145 and its sihf null mutant BG716 were grown on minimal media agar plates containing various carbon and nitrogen sources. As a result, BG716 showed strongly delayed and less pronounced
Fig. 3 Differential antibiotic production of S. coelicolor M145 and its sihf null mutant BG716 when cultured on various minimal media and $\mathrm{R}^{-}$ complex media (a).

Complementation of BG716 with SCO1480 (BG7161 and $\mathrm{BG7165)}$ grown on minimal media containing glucose and glycine for 6 days. SIHF is cloned in a multi-copy vector with the ermE* promoter (BG7161) and in an integration vector containing the native promoter of sihf (BG7165) (b). Measurement of ACT (c) and undecylprodigiosin (d) of M145 and BG716 when cultured on $\mathrm{R}^{-}$ media
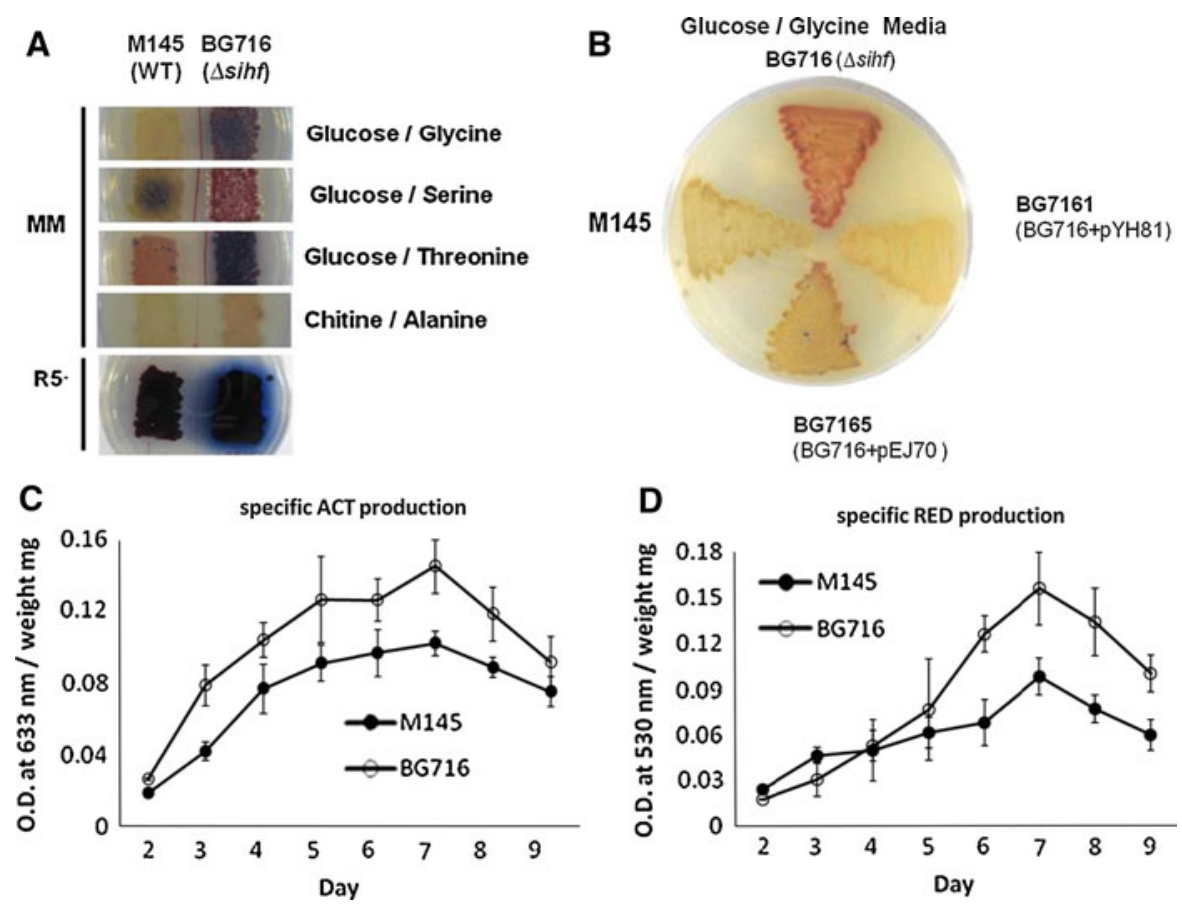


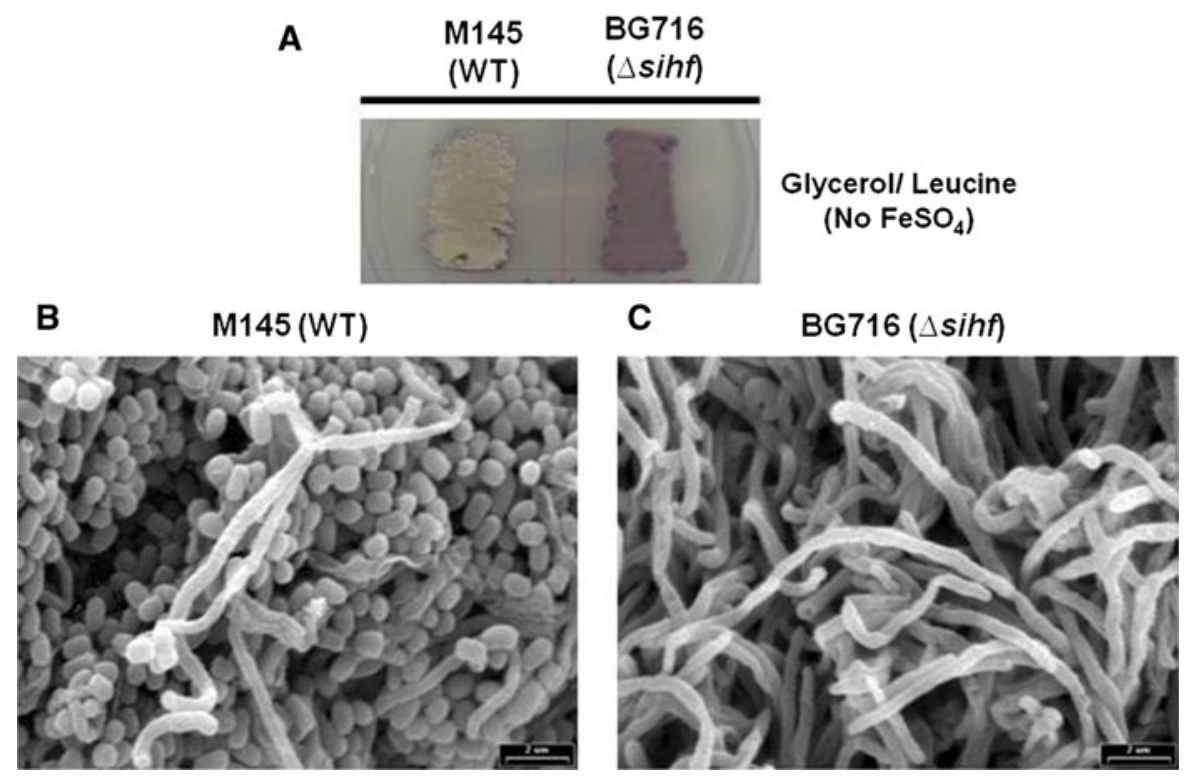

Fig. 4 Comparison of sporulation of S. coelicolor M145 and its sihf null mutant BG716. a Both strains grown on $\mathrm{Fe}^{2+}$-deficient minimal media containing glycerol and leucine. b, c Scanning electron micrographs of M145 (b) and BG716 (c) at $\times 5,000$

sporulation on both MM and R5 ${ }^{-}$agar plates. This effect was particularly strong when grown on MM with glycerol and leucine as carbon and nitrogen sources without $\mathrm{FeSO}_{4} \cdot 7 \mathrm{H}_{2} \mathrm{O}$ (normally $36 \mu \mathrm{M}$ ) (Fig. 4a). Surprisingly, while the parental strain M145 showed normal sporulation on these irondepleted media, BG716 failed to produce spores. Using cryo-scanning electron microscopy (cryo-SEM) the difference in sporulation between M145 and BG716 was clearly visible (Fig. 4b, c), with BG716 hardly producing any spores.

Interestingly, the $\operatorname{sihf}$ mutant spores had an increased spores size, from $1.2 \pm 0.2 \mu \mathrm{m}$ for M145 to $1.5 \pm 0.4 \mu \mathrm{m}$ for the sihf null mutant (Fig. 5); the average spore size was restored to the wild-type range of $1.2 \pm 0.4 \mu \mathrm{m}$ by complementation with wild-type sihf (strain BG7161). Additionally, fluorescence microscopy of the chromosome revealed that SIHF did not affect DNA distribution during vegetative growth (Supplementary Fig. 2), but that it is very important for the correct DNA segregation during sporulation. Comparison of the integrity of the aerial hyphae and spores of M145, BG716, and BG7161 by live/dead staining revealed a high proportion of dead cells in the mutant BG716, while hardly any were found in the parental strain M145 (Fig. 5). The viability was magnification. Note that the sihf null mutant fails to sporulate on glycerol/leucine minimal media without $\mathrm{Fe}^{2+}$ ion, while the parental strain M145 does produce spores under these conditions

restored when the mutant was complemented with a vector expressing sihf (strain BG7161). In sihf null mutants a significant proportion of the spores $(10.2 \%$ of a total of 500 counted spores) were empty, i.e. not containing any DNA, while the DNA content of the spores that did contain DNA measured by the fluorescence intensities varied significantly (Fig. 5; Table 2, $F$ test $P$ value $<0.001$ ). Additionally, the percentage of damaged spores (i.e. stained with propidium iodide) increased to $4.3 \%$. In both the parental strain and the complemented mutant BG7161 no empty spores were observed and damaged spores were observed with a frequency of less than $1 \%$ (Table 2).

These live/dead imaging data clearly indicate that the hyphae and spores of the mutant are less viable, and we anticipated that they would therefore also be more sensitive to general stresses such as heat shock. Therefore, S. coelicolor M145, sihf mutant BG716, and a strain with enhanced expression of sIHF (BG7164) were analyzed in a heat inactivation experiment as described in the "Materials and methods" section. After $10 \mathrm{~min}$ of incubation at $60^{\circ} \mathrm{C}$, most cells of BG716 had died (15\% survival based on cfu counts), whereas M145 and BG7164 were much less affected, displaying relatively high viable counts of 50 and $64 \%$, respectively (Fig. 6). After $20 \mathrm{~min}$ of heat 

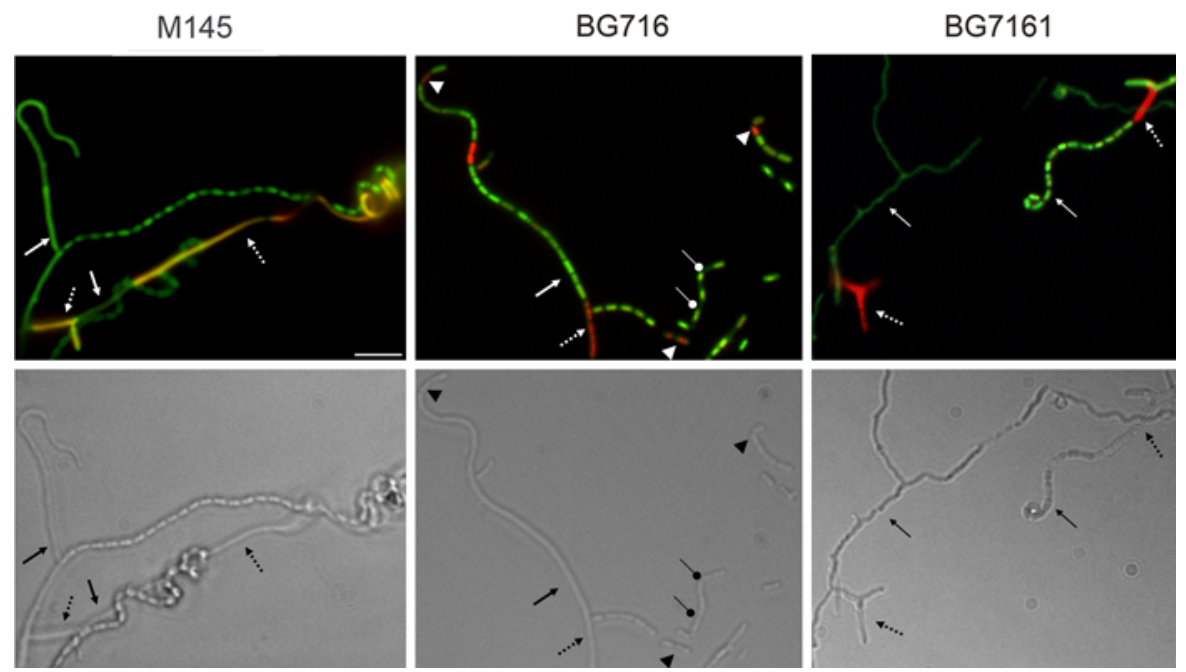

Fig. 5 Live/dead staining (top) of S. coelicolor of M145 (left), BG716 (SCO1480 deletion mutant, middle), and BG7161 (complementation strain, right) with their corresponding light images (bottom). Strains were grown on SFM for 4 days. Dashed arrows mark lysing (dead) aerial hyphae, solid arrows mark viable aerial hyphae. Arrowheads mark dead spores and

Table 2 Live/dead staining and size distribution of the spores

\begin{tabular}{|c|c|c|c|}
\hline & M145 & BG716 & BG7161 \\
\hline \multicolumn{4}{|c|}{ Live/dead staining } \\
\hline Live & $99.8 \%$ & $85.5 \%$ & $99.6 \%$ \\
\hline Dead & $0.2 \%$ & $4.3 \%$ & $0.4 \%$ \\
\hline Empty & $0.0 \%$ & $10.2 \%$ & $0.0 \%$ \\
\hline \multicolumn{4}{|l|}{ Spore size } \\
\hline Size $(\mu \mathrm{m})$ & $1.2 \pm 0.4$ & $1.5 \pm 0.2$ & $1.2 \pm 0.2$ \\
\hline
\end{tabular}

For each strain 500 spores were counted. See also Fig. 5

treatment, no survival was observed for BG716, whereas for M145 and BG7164 a survival was found of 26 and $57 \%$, respectively. The higher survival for BG7164 was reproducible. When the viability test was done with the spores, the survival rate of BG716 was reduced more than half compared to that of mycelia (data not shown). These results suggest that although sIHF is not essential, it is very important for governing cell viability.

Proteome analysis of the sihf null mutant

To obtain more insight into the physiological role of sIHF, we compared the protein expression profiles of the mutant and the parental strain using comparative $2 \mathrm{D}$-gel balloon heads mark empty spores. Note that these are only observed in the SCO1480 deletion strain, whereas viable and dead aerial hyphae occur both in wild type and BG7161 as well as BG716. For statistics of live/dead spores and spore sizes see Table 2. Bar, $5 \mu \mathrm{m}$

analysis. For this, M145 and BG716 were cultured on MM agar plates with glucose and glycine (MMGG) for 5 days. MMGG was chosen because BG716 showed distinctive differences in antibiotic production and morphology on this media as compared to M145. Differentially expressed proteins $(>1.5$ fold difference and at least 3 peptides identified by mass spectrometry) are listed in Tables $3 \mathrm{~A}$ and B. Glycine was added, as it is one of the precursors for RED biosynthesis in $S$. coelicolor. As expected, BG716 produced more RED compared to M145 when they were grown in MMGG. Glycine-utilizing pathways were up-regulated in BG716, such as serine hydroxymethyltransferase (SCO4837), which converts glycine into serine, and phosphoserine aminotransferase (SCO4366), which is involved in converting serine into 3-phosphoglycerate, a glycolytic intermediate. This suggests that enhanced RED production in BG716 may be caused by the elevated expression levels of glycine-utilizing pathways.

Interestingly, SCO5080 (ActVA5) was also enhanced in the mutant, in line with the enhanced ACT production in BG716. In addition, antibiotic repressor CutR (SCO5862) was down-regulated in BG716. The two-component signal transduction system CutRS of S. lividans which is known to be closely related to $S$. coelicolor, was reported to repress antibiotic production in both $S$. lividans and 


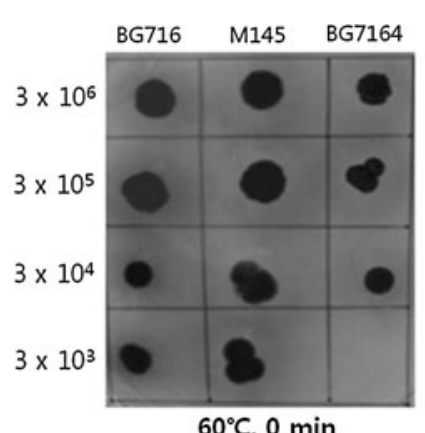

$60^{\circ} \mathrm{C}, 0 \mathrm{~min}$

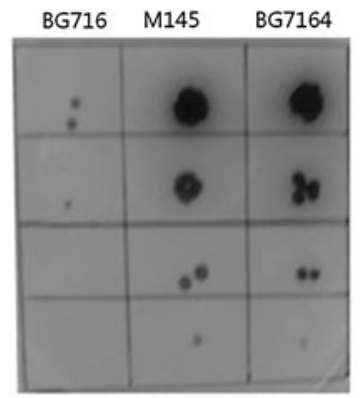

$60^{\circ} \mathrm{C}, 10 \mathrm{~min}$

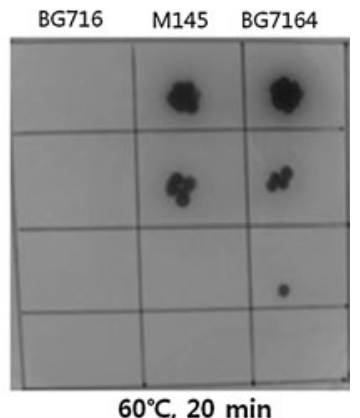

$60^{\circ} \mathrm{C}, 20 \mathrm{~min}$
Fig. 6 Viability test of M145, BG716 (SCO1480 deletion mutant), and BG7164 (M145 with sihf behind $\mathrm{p}_{\text {ermE* }}$ on a multicopy vector) after the heat treatment at $60^{\circ} \mathrm{C}$ for 0,10 , and $20 \mathrm{~min}$. Strains were cultured in $25 \mathrm{ml} \mathrm{R}^{-}$liquid media for $20 \mathrm{~h}$, and the cells were harvested and taken the same amount of

S. coelicolor (Chang et al. 1996). Therefore, the reduced protein level of CutR again correlates well to the increased antibiotic production in BG716.

Five putative transcriptional regulators (SCO0132, SCO5862, SCO1654, SCO5811 and SCO7785) were found to be differentially expressed in BG716 (Table 3). Furthermore, the YidC protein (SCO3883), which is part of the secretion machinery and assists in the integration, folding, and assembly of inner membrane proteins into the membrane (Luirink et al. 2005), showed three-fold reduction in expression in the sihf mutant, while the cytoskeletal protein FilP (Bagchi et al. 2008) could not be identified in the mutant and was readily identified in the parental strain M145. These major changes highlight the global role for sihf. In the previous studies on deletion mutants of more specific transcriptional regulators, only one or two transcriptional regulators were found to be differentially expressed in comparative 2D-gel analysis (Yang et al. 2009, 2010). Our results suggest that sIHF may govern several lower-level transcriptional regulators, and act as a global and upper-level regulator in the hierarchical transcriptional network, along with other important global regulators like DasR (Rigali et al. 2006, 2008) and BldD (den Hengst et al. 2010). All of these regulators have a major effect on both development and antibiotic production.

\section{Discussion}

Global control of cell-cycle and antibiotic regulators is controlled by distinct classes of regulatory elements in cfus. Note the strongly enhanced sensitivity of the submerged mycelia to high temperatures, with viability more than two orders of magnitude lower than of mycelia from the parental strain M145 and of BG7164

streptomycetes. Their saprophytic life style and complex life cycle necessitates complex transcriptional control, exerted by well-studied regulators such as AdpA (which responds to the $\gamma$-butyrolactone A-factor), the cAMP receptor protein CRP (pleiotropic regulator of germination and early growth), the nutrient sensor DasR (switch to development), the global amino acid regulator $\mathrm{NdgR}$ and the developmental Bld and Whi regulators (Bibb 1996; Flardh and Buttner 2009; Ohnishi et al. 2005; Piette et al. 2005; Rigali et al. 2006; van Wezel et al. 2009; Yang et al. 2009). A second category of regulators globally affects gene regulation at the level of translation, most notably the rare leucyl-tRNA BldA, which relates to developmental control of TTA-containing genes (Lawlor et al. 1987), and tmRNA, which is essential for the translation of antibiotic- and stressrelated genes such as $\operatorname{dnaK}, \operatorname{dasR}, \operatorname{ssg} R A$ and tipA (Barends et al. 2010).

Contrary to these DNA-binding regulators, only a few studies were exerted to the understanding of the basic architectural elements in streptomycetes. SCO2950 was revealed to be a conventional nucleoid-associated $\mathrm{HU}$ protein that is similar to E. coli $\mathrm{HU} \alpha$ and $\mathrm{HU} \beta$, whereas the two-domain HU protein SCO5556 exists only in actinobacteria (Salerno et al. 2009). SCO5556 is specifically expressed during sporulation, while SCO2950 is active during vegetative growth. Spores of a SCO5556 deletion mutant had an increased average nucleoid size as compared to the parental strain and were defective in heat resistance (Salerno et al. 2009). In other species such as E. coli, these proteins are known to be involved in the control 
Table 3 Lists of differentially expressed proteins in BG716

Spot ID Annotation

\begin{tabular}{|c|c|}
\hline 1318 & FumC, fumarate hydratase $\mathrm{C}$ \\
\hline \multirow[t]{2}{*}{1329} & Dxr, 1-deoxy-D-xylulose 5-phosphate reductoisomerase \\
\hline & XylB, xylulose kinase \\
\hline 1343 & SucC, succinyl-CoA synthetase beta chain \\
\hline 1395 & Gap2, glyceraldehyde 3-phosphate dehydrogenase \\
\hline \multirow[t]{2}{*}{1414} & Mdh, malate dehydrogenase \\
\hline & Putative inner membrane protein translocase component YidC \\
\hline 1415 & Cytoskeletal protein FilP \\
\hline \multirow[t]{2}{*}{1499} & Pgm, phosphoglyceromutase \\
\hline & InfC, translation initiation factor IF-3 \\
\hline \multirow[t]{2}{*}{1531} & Probable transcriptional regulator \\
\hline & Beta-xylosidase \\
\hline 1539 & RNA polymerase sigma factor \\
\hline \multirow[t]{2}{*}{1542} & CutR, two-component regulator CutR \\
\hline & Putative two-component response regulator \\
\hline 1546 & Transcriptional regulator \\
\hline 1553 & Tellurium resistance protein \\
\hline 1433 & HisA, phosphoribosyl isomerase A \\
\hline 1591 & Hypothetical protein \\
\hline 1615 & RplL, 50S ribosomal protein $\mathrm{L} 7 / \mathrm{L} 12$ \\
\hline
\end{tabular}

(B) Proteins that were overrepresented (more than 1.5-fold) in sihf null mutant BG716

\begin{tabular}{|c|c|c|c|c|c|}
\hline \multirow[t]{2}{*}{1214} & GlyA, serine hydroxymethyltransferase & SCO4837 & 94 & 6 & $\mathrm{O}$ \\
\hline & PdhL, dihydrolipoamide dehydrogenase & SCO2180 & 7 & 2 & \\
\hline \multirow[t]{2}{*}{1253} & Acetyl-CoA acetyltransferase & SCO3079 & 105 & 7 & 2.2 \\
\hline & Dipeptidase & SCO3058 & 5 & 2 & \\
\hline 1254 & Phosphoserine aminotransferase & SCO4366 & 52 & 3 & 1.8 \\
\hline 1270 & Hydrolase (ACT cluster) & SCO5080 & 4 & 2 & 2.3 \\
\hline 1273 & Gap1, glyceraldehyde-3-phosphate dehydrogenase & SCO1947 & 221 & 8 & 2.2 \\
\hline \multirow[t]{2}{*}{1339} & Oxidoreductase & SCO4266 & 238 & 4 & $\mathrm{O}$ \\
\hline & Transcriptional regulator & SCO7785 & 7 & 2 & \\
\hline 1346 & PcrA, 20S proteasome alpha-subunit & SCO1643 & 29 & 2 & 1.8 \\
\hline 1380 & TpiA, triosephosphate isomerase & SCO1945 & 125 & 5 & $\mathrm{O}$ \\
\hline \multirow[t]{2}{*}{1474} & Decarboxylase & SCO2822 & 28 & 2 & $\mathrm{O}$ \\
\hline & Nucleotide binding protein & SCO4614 & 4 & 2 & \\
\hline 1475 & MoaB, molybdenum cofactor biosynthesis protein (putative secreted protein) & SCO3179 & 7 & 2 & 2.8 \\
\hline 1483 & CvnA9, integral membrane protein & SCO1630 & 4 & 2 & $\mathrm{O}$ \\
\hline 1496 & Secreted protein & SCO1860 & 52 & 2 & $\mathrm{O}$ \\
\hline 1498 & PanD, L-aspartate-alpha-decarboxylase & SCO0978 & 89 & 2 & $\mathrm{O}$ \\
\hline 1401 & Map2, methionine aminopeptidase & SCO6409 & 79 & 3 & 1.7 \\
\hline
\end{tabular}

Spots that were only present in BG716 or M145 gels were indicated as O 
of many operons by either affecting the DNA architecture or transcription (Goosen and van de Putte 1995). Architectural proteins are more likely to globally affect transcription, which affect other regulators by interfering with or assisting in the binding of regulators at the same binding site (Devroede et al. 2006).

mIHF was first found in M. smegmatis and Mycobacterium tuberculosis, where it stimulates the integration of mycobaceriophage L5 (Pedulla et al. 1996). Many homologs were found in the genomes of mycobacteria, corynebacteria, streptomycetes, and rhodococci. In mycobacteria, $\mathrm{mIHF}$ is essential for survival and while involvement in secondary metabolism was not yet reported, the strong increase in concentration of mIHF at the stationary phase suggests its involvement in processes relating to secondary metabolism and stationary events (Pedulla and Hatfull 1998). In the life cycle of streptomycetes this phase corresponds to antibiotic production and morphological differentiation.

More information on the general function of this important gene in Mycobacterium may be gleaned from the phenotype of the sihf mutant in S. coelicolor, although some caution should be taken as Mycobacterium and Streptomyces are rather distantly related members of the family of actinomycetales. In previous studies, IHFs were shown to reach their highest intracellular levels just prior to the stationary phase, and were known to be involved in the regulation of genes required for the establishment of the stationary phase (Aviv et al. 1994; Ditto et al. 1994; HenggeAronis 1996). In addition, mIHF is most abundant prior to entry into the stationary phase even though its effect is weaker than of other IHFs. It is also proposed to regulate the expression of stationary phase-specific genes similar to the E. coli IHF (Pedulla and Hatfull 1998). The effect on sporulation and antibiotic production indeed seems to support a dominant role for SIHF in the control of stationary phase-specific gene regulation in streptomycetes.

In support of this growth phase-dependence, we observed major changes in spore morphology and integrity. The average spore size increased by around $25 \%$, from an average of 1.2 for the parental strain and the complemented mutant to $1.5 \mu \mathrm{m}$ for the sihf null mutant. Live/dead staining further demonstrated significant changes in spore integrity and DNA distribution. While no significant changes were observed during vegetative growth, around $10 \%$ of the sihf mutant spores were empty, i.e. not containing any DNA, while some $4 \%$ damaged or dead spores (i.e. stained with propidium iodide) were found (Table 2). This demonstrates that sIHF becomes more important for integrity of the cells and proper DNA segregation at later stages of the Streptomyces life cycle.

The onset of antibiotic production and sporulation are highly coordinated (Bibb 2005; van Wezel and McDowall 2011), with antibiotic production typically coinciding with growth cessation in response to the accumulation of ppGpp (Chakraburtty and Bibb 1997; Strauch et al. 1991). The occurrence of many mutants deficient in both antibiotic production and the formation of aerial hyphae suggests that these processes are partially controlled by the same set of regulators (Bibb 2005; Chater 2001; Rigali et al. 2008; Uguru et al. 2005). Our data show that sIHF functions in a distinctly different manner, repressing antibiotic production and ensuring correct and abundant sporulation. Proteomic data show down-regulation of the antibiotic repressor CutR, membrane assembly protein YidC, and cytoskeletal protein FilP in BG716, which suggests that SIHF acts as a repressor of antibiotic production and plays a role in the control of morphological differentiation. Although sIHF could be affected by different nutrients, this is a rare example of a regulatory gene oppositely governing the two main developmental events. Thus it appears that sIHF has more complex and versatile effects than originally expected in terms of the control of chemical and morphological differentiation.

Acknowledgments This work was supported by WCU (World Class University) program (R322009000102130), NRL (National Research Lab) program (20090083035), and Basic Science Research Program (2010-0009942) through the National Research Foundation (NRF) grant funded by the Korean government (MEST), and by a VICI grant from the Dutch applied research council (STW) to GPvW.

\section{References}

Aviv M, Giladi H, Schreiber G, Oppenheim AB, Glaser G (1994) Expression of the genes coding for the Escherichia coli integration host factor are controlled by growth phase, rpoS, ppGpp and by autoregulation. Mol Microbiol 14(5):1021-1031

Bagchi S, Tomenius H, Belova LM, Ausmees N (2008) Intermediate filament-like proteins in bacteria and a 
cytoskeletal function in Streptomyces. Mol Microbiol 70(4):10371050

Barends S, Zehl M, Bialek S, de Waal E, Traag BA, Willemse J, Jensen ON, Vijgenboom E, van Wezel GP (2010) Transfermessenger RNA controls the translation of cell-cycle and stress proteins in Streptomyces. EMBO Rep 11(2):119-125

Benson DA, Boguski MS, Lipman DJ, Ostell J, Ouellette BF (1998) GenBank. Nucleic Acids Res 26(1):1-7

Bentley SD, Chater KF, Cerdeno-Tarraga AM, Challis GL, Thomson NR, James KD, Harris DE, Quail MA, Kieser H, Harper D, Bateman A, Brown S, Chandra G, Chen CW, Collins M, Cronin A, Fraser A, Goble A, Hidalgo J, Hornsby T, Howarth S, Huang CH, Kieser T, Larke L, Murphy L, Oliver K, O’Neil S, Rabbinowitsch E, Rajandream MA, Rutherford K, Rutter S, Seeger K, Saunders D, Sharp S, Squares R, Squares S, Taylor K, Warren T, Wietzorrek A, Woodward J, Barrell BG, Parkhill J, Hopwood DA (2002) Complete genome sequence of the model actinomycete Streptomyces coelicolor A3(2). Nature 417(6885): 141-147

Bibb M (1996) 1995 Colworth Prize Lecture. The regulation of antibiotic production in Streptomyces coelicolor A3(2). Microbiology 142(Pt 6):1335-1344

Bibb MJ (2005) Regulation of secondary metabolism in Streptomycetes. Curr Opin Microbiol 8(2):208-215

Bierman M, Logan R, O'Brien K, Seno ET, Rao RN, Schoner BE (1992) Plasmid cloning vectors for the conjugal transfer of DNA from Escherichia coli to Streptomyces spp. Gene 116(1):43-49

Boubrik F, Bonnefoy E, Rouviere-Yaniv J (1991) HU and IHF: similarities and differences. In Escherichia coli, the lack of HU is not compensated for by IHF. Res Microbiol 142(2-3):239-247

Chakraburtty R, Bibb M (1997) The ppGpp synthetase gene (relA) of Streptomyces coelicolor A3(2) plays a conditional role in antibiotic production and morphological differentiation. J Bacteriol 179(18):5854-5861

Chang HM, Chen MY, Shieh YT, Bibb MJ, Chen CW (1996) The cutRS signal transduction system of Streptomyces lividans represses the biosynthesis of the polyketide antibiotic actinorhodin. Mol Microbiol 21(5):1075-1085

Charlier D, Hassanzadeh G, Kholti A, Gigot D, Pierard A, Glansdorff N (1995) carP, involved in pyrimidine regulation of the Escherichia coli carbamoylphosphate synthetase operon encodes a sequence-specific DNA-binding protein identical to XerB and PepA, also required for resolution of ColEI multimers. J Mol Biol 250(4):392-406

Chater KF (2001) Regulation of sporulation in Streptomyces coelicolor A3(2): a checkpoint multiplex? Curr Opin Microbiol 4(6):667-673

Cole ST, Brosch R, Parkhill J, Garnier T, Churcher C, Harris D, Gordon SV, Eiglmeier K, Gas S, Barry CE III, Tekaia F, Badcock K, Basham D, Brown D, Chillingworth T, Connor R, Davies R, Devlin K, Feltwell T, Gentles S, Hamlin N, Holroyd S, Hornsby T, Jagels K, Krogh A, McLean J, Moule S, Murphy L, Oliver K, Osborne J, Quail MA, Rajandream MA, Rogers J, Rutter S, Seeger K, Skelton J, Squares R, Squares S, Sulston JE, Taylor K, Whitehead S, Barrell BG (1998) Deciphering the biology of
Mycobacterium tuberculosis from the complete genome sequence. Nature 393(6685):537-544

den Hengst CD, Tran NT, Bibb MJ, Chandra G, Leskiw BK, Buttner MJ (2010) Genes essential for morphological development and antibiotic production in Streptomyces coelicolor are targets of BldD during vegetative growth. Mol Microbiol 78(2):361-379

Devroede N, Huysveld N, Charlier D (2006) Mutational analysis of intervening sequences connecting the binding sites for integration host factor, PepA, PurR, and RNA polymerase in the control region of the Escherichia coli carAB operon, encoding carbamoylphosphate synthase. J Bacteriol 188(9):3236-3245

Ditto MD, Roberts D, Weisberg RA (1994) Growth phase variation of integration host factor level in Escherichia coli. J Bacteriol 176(12):3738-3748

Flardh K, Buttner MJ (2009) Streptomyces morphogenetics: dissecting differentiation in a filamentous bacterium. Nat Rev Microbiol 7(1):36-49

Goosen N, van de Putte P (1995) The regulation of transcription initiation by integration host factor. Mol Microbiol 16(1):1-7

Gust B, Challis GL, Fowler K, Kieser T, Chater KF (2003) PCRtargeted Streptomyces gene replacement identifies a protein domain needed for biosynthesis of the sesquiterpene soil odor geosmin. Proc Natl Acad Sci USA 100(4):1541-1546

Guthrie EP, Flaxman CS, White J, Hodgson DA, Bibb MJ, Chater KF (1998) A response-regulator-like activator of antibiotic synthesis from Streptomyces coelicolor A3(2) with an amino-terminal domain that lacks a phosphorylation pocket. Microbiology 144(Pt 3):727-738

Hengge-Aronis R (1996) Back to log phase: sigma $S$ as a global regulator in the osmotic control of gene expression in Escherichia coli. Mol Microbiol 21(5):887-893

Kano Y, Ogawa T, Ogura T, Hiraga S, Okazaki T, Imamoto F (1991) Participation of the histone-like protein HU and of IHF in minichromosomal maintenance in Escherichia coli. Gene 103(1):25-30

Karp PD, Riley M, Saier M, Paulsen IT, Collado-Vides J, Paley SM, Pellegrini-Toole A, Bonavides C, Gama-Castro S (2002) The EcoCyc database. Nucleic Acids Res 30(1):56-58

Kieser T, Bibb MJ, Buttner MJ, Chater K, Hopwood DA (2000) Practical Streptomyces genetics. Mol Microbiol, vol 3. John Innes Centre, Norwich Research Park, Colney, Norwich

Lawlor EJ, Baylis HA, Chater KF (1987) Pleiotropic morphological and antibiotic deficiencies result from mutations in a gene encoding a tRNA-like product in Streptomyces coelicolor A3(2). Genes Dev 1(10):1305-1310

Lee CJ, Won HS, Kim JM, Lee BJ, Kang SO (2007) Molecular domain organization of BldD, an essential transcriptional regulator for developmental process of Streptomyces coelicolor A3(2). Proteins 68(1):344-352

Luirink J, von Heijne G, Houben E, de Gier JW (2005) Biogenesis of inner membrane proteins in Escherichia coli. Annu Rev Microbiol 59:329-355

Mangan MW, Lucchini S, Danino V, Croinin TO, Hinton JC, Dorman CJ (2006) The integration host factor (IHF) integrates stationary-phase and virulence gene expression in 
Salmonella enterica serovar Typhimurium. Mol Microbiol 59(6):1831-1847

Nicholas HB Jr, Ropelewski AJ, Deerfield DW II (2002) Strategies for multiple sequence alignment. BioTechniques 32(3):572-574, 576, 578 passim

Ohnishi Y, Yamazaki H, Kato JY, Tomono A, Horinouchi S (2005) AdpA, a central transcriptional regulator in the A-factor regulatory cascade that leads to morphological development and secondary metabolism in Streptomyces griseus. Biosci Biotechnol Biochem 69(3):431-439

Park SS, Yang YH, Song E, Kim EJ, Kim WS, Sohng JK, Lee HC, Liou KK, Kim BG (2009) Mass spectrometric screening of transcriptional regulators involved in antibiotic biosynthesis in Streptomyces coelicolor A3(2). J Ind Microbiol Biotechnol 36(8):1073-1083

Pedulla ML, Hatfull GF (1998) Characterization of the mIHF gene of Mycobacterium smegmatis. J Bacteriol 180(20): 5473-5477

Pedulla ML, Lee MH, Lever DC, Hatfull GF (1996) A novel host factor for integration of mycobacteriophage L5. Proc Natl Acad Sci USA 93(26):15411-15416

Piette A, Derouaux A, Gerkens P, Noens EE, Mazzucchelli G, Vion S, Koerten HK, Titgemeyer F, De Pauw E, Leprince P, van Wezel GP, Galleni M, Rigali S (2005) From dormant to germinating spores of Streptomyces coelicolor A3(2): new perspectives from the crp null mutant. J Proteome Res 4(5):1699-1708

Rice PA (1997) Making DNA do a U-turn: IHF and related proteins. Curr Opin Struct Biol 7(1):86-93

Rigali S, Nothaft H, Noens EE, Schlicht M, Colson S, Muller M, Joris B, Koerten HK, Hopwood DA, Titgemeyer F, van Wezel GP (2006) The sugar phosphotransferase system of Streptomyces coelicolor is regulated by the GntR-family regulator DasR and links $N$-acetylglucosamine metabolism to the control of development. Mol Microbiol 61(5): 1237-1251

Rigali S, Titgemeyer F, Barends S, Mulder S, Thomae AW, Hopwood DA, van Wezel GP (2008) Feast or famine: the global regulator DasR links nutrient stress to antibiotic production by Streptomyces. EMBO Rep 9(7):670-675

Salerno P, Larsson J, Bucca G, Laing E, Smith CP, Flardh K (2009) One of the two genes encoding nucleoid-associated HU proteins in Streptomyces coelicolor is developmentally regulated and specifically involved in spore maturation. J Bacteriol 191(21):6489-6500

Strauch E, Takano E, Baylis HA, Bibb MJ (1991) The stringent response in Streptomyces coelicolor A3(2). Mol Microbiol 5(2):289-298

Streptomyces database website. http://strepdb.streptomyces. org.uk/

Takeuchi A, Matsumura H, Kano Y (2002) Cloning and expression in Escherichia coli of a gene, hup, encoding the histone-like protein HU of Bifidobacterium longum. Biosci Biotechnol Biochem 66(3):598-603

Tamura K, Peterson D, Peterson N, Stecher G, Nei M, Kumar S (2011) MEGA5: molecular evolutionary genetics analysis using maximum likelihood, evolutionary distance, and maximum parsimony methods. Mol Biol Evol 28(10): 2731-2739

Thompson JD, Gibson TJ, Plewniak F, Jeanmougin F, Higgins DG (1997) The CLUSTAL_X windows interface: flexible strategies for multiple sequence alignment aided by quality analysis tools. Nucleic Acids Res 25(24):4876-4882

Thuy ML, Kharel MK, Lamichhane R, Lee HC, Suh JW, Liou K, Sohng JK (2005) Expression of 2-deoxy-scyllo-inosose synthase (kanA) from kanamycin gene cluster in Streptomyces lividans. Biotechnol Lett 27(7):465-470

Uguru GC, Stephens KE, Stead JA, Towle JE, Baumberg S, McDowall KJ (2005) Transcriptional activation of the pathway-specific regulator of the actinorhodin biosynthetic genes in Streptomyces coelicolor. Mol Microbiol 58(1): 131-150

van Wezel GP, McDowall KJ (2011) The regulation of the secondary metabolism of Streptomyces: new links and experimental advances. Nat Prod Rep 28(7):1311-1333

van Wezel GP, McKenzie NL, Nodwell JR (2009) Chapter 5. Applying the genetics of secondary metabolism in model actinomycetes to the discovery of new antibiotics. Methods Enzymol 458:117-141

Willemse J, van Wezel GP (2009) Imaging of Streptomyces coelicolor A3(2) with reduced autofluorescence reveals a novel stage of FtsZ localization. PLoS One 4(1):e4242

Willemse J, Borst JW, de Waal E, Bisseling T, van Wezel GP (2011) Positive control of cell division: FtsZ is recruited by SsgB during sporulation of Streptomyces. Genes Dev 25(1):89-99

Yang YH, Joo HS, Lee K, Liou KK, Lee HC, Sohng JK, Kim BG (2005) Novel method for detection of butanolides in Streptomyces coelicolor culture broth, using a His-tagged receptor (ScbR) and mass spectrometry. Appl Environ Microbiol 71(9):5050-5055

Yang YH, Song E, Kim EJ, Lee K, Kim WS, Park SS, Hahn JS, Kim BG (2009) NdgR, an IclR-like regulator involved in amino-acid-dependent growth, quorum sensing, and antibiotic production in Streptomyces coelicolor. Appl Microbiol Biotechnol 82(3):501-511

Yang YH, Song E, Lee BR, Kim EJ, Park SH, Kim YG, Lee CS, Kim BG (2010) Rapid functional screening of Streptomyces coelicolor regulators by use of a $\mathrm{pH}$ indicator and application to the MarR-like regulator AbsC. Appl Environ Microbiol 76(11):3645-3656 